\title{
Diameter and height distributions in a gallery forest tree community and some of its main species in central Brazil over a six-year period (1985-1991)
}

\author{
JEANINE MARIA FELFILI ${ }^{1}$
}

(recebido em 22/06/95; aceito em 26/12/96)

\begin{abstract}
Diameter and height distributions in a gallery forest tree community and some of its main species in central Brazil over a six-year period (1985-1991)). The diameter and height structure were studied over six years in approximately 64 ha of the Gama gallery forest in Brasília, DF. Trees from $10 \mathrm{~cm}$ dbh were measured every three years from 1985 in $151(10$ x $20 \mathrm{~m})$ permanent plots. Natural regeneration (individuals under $10 \mathrm{~cm} \mathrm{dbh}$ ) was measured in subplots within the $200 \mathrm{~m}^{2}$ plots. Most individuals and species were under $45 \mathrm{~cm}$ diameter and $20 \mathrm{~m}$ high while the maximum diameter for individual species ranged from 30 to $95 \mathrm{~cm}$. The diameter structure was typical of a mixed tropical forest with the number of individuals decreasing with increasing size classes and showing little change over the six years. The most abundant species occupy different positions in the canopy and have different size structures.
\end{abstract}

RESUMO - (Distribuições de diâmetros e de alturas de uma comunidade arbórea e algumas das principais espécies no Brasil central ao longo de um período de seis anos (1985-1991)). A distribuição de diâmetros e alturas foi estudada num trecho de 64 ha da mata de galeria do Ribeirão do Gama em Brasília, DF. Árvores a partir de $10 \mathrm{~cm}$ de diâmetro foram medidas a intervalos de três anos desde 1985 em 151 parcelas permanentes de $10 \times 20 \mathrm{~m}$. A regeneração natural (indivíduos com diâmetros inferiores a $10 \mathrm{~cm}$ ) foi medida em subparcelas dentro das parcelas de $200 \mathrm{~m}^{2}$. Os limites máximos atingidos pela maioria dos indivíduos e espécies foram $45 \mathrm{~cm}$ de diâmetro e $20 \mathrm{~m}$ de altura. O diâmetro máximo atingido pelas espécies individualmente variou de 30 a $95 \mathrm{~cm}$. A distribuição diamétrica foi típica de florestas nativas com o número de indivíduos decrescendo com o incremento das classes diamétricas e mudando pouco durante os seis anos. As espécies mais abundantes ocupam diferentes estratos e têm distribuições diamétrica e de alturas distintas.

Key words - Diameter, height, gallery forest, tropics, community structure

\section{Introducion}

The distribuition of diameters is a reflection of the history of the forest (Meyer et al. 1961). In balanced forests, there is a dynamic equilibrium between mortality and growth (Leak 1964, Harper 1977).

Several authors have analysed the diameter distribution in tropical forests (Richards 1952, Hubbell \& Foster 1987, Campbell et al. 1992). They found a reversed-J tendency when all individuals of all species were combined. Some individual species, mainly those in the middle and lower stories also show this tendency. However, the distribution of many large top canopy species does not follow this pattern. Most species have relatively few individuals in the smaller sizes, suggesting little regeneration in more recent years. Another pattern is that with most of the individuals in the smaller sizes. Hubbell \& Foster (1987) and Clark \& Clark $(1987,1992)$ point out that for some species, an adequate analysis of all size classes should be done on a large spatial scale. Thus, most of the tree inventory plots used in

1. Departamento de Engenharia Florestal, Universidade de Brasília, Caixa Postal 04357, 70900-900, DF, Brasil. previous studies would be inadequate for an accurate analysis of all life history phases.

Some studies in central Brazil have confirmed the reversed-J pattern for different woody formations. For example, the transition between dry and Amazonian forests (Felfili 1983), cerrado sensu stricto (Felfili \& Silva Junior 1988, Silva Junior \& Silva 1988, Nascimento \& Saddi 1992), dry mesophytic forests (Ramos 1989) and montane semideciduous forest (Oliveira-Filho et al. 1994). The distribution of individual species also varied (Moreira 1987, Felfili \& Silva Junior 1988, Silva Junior \& Silva 1988 and Oliveira et al. 1989).

Gallery forests are narrow strips of forests surrounded by savanna vegetation. Wind, streamflow, fires and other environmental stresses in the surrounding vegetation have a strong role in the dynamic of these ecosystems (Felfili 1993, Kellman et al. 1994, Felfili, 1997). Recruitment and mortality rates are higher than in continuous formations such us the Amazonian rainforests (Felfili 1993, 1995) but tend to compensate each other over time. Gallery forest trees seem to have a shorter longevity than trees of the same species in continuous formations (Mac Dougan \& Kellman 1992, Kellman et al. 1994). This is probably due to more intense 
environmental stresses which causes higher mortality rates in those formations (Felfili 1993, 1995). According to Felfili (1993, 1995), most of the gallery forest species have a continuous distribution in the forest. However, some species are preferential to gaps, streambank or to the edges with savanna.

Regarding the gallery forests, the hypothesis are: 1. Gallery forests are in a dynamic equilibrium so, the diameter distribution for the community should show a decreasing tendency and remain fairly constant over time.

2. The size distribution of individual species should vary according to their ecological requirements and their patterns of spatial distribution, as in several other continous forest formations.

This research aims to analyse the Gama gallery forest size structure over time. A characterisation of the vertical structure and bole shape is also attempted.

\section{Material and methods}

This study was conducted in an area of 64 ha in the Gama gallery forest in Fazenda Água Limpa (15 $56^{\prime}$ - 1559'S and $\left.47^{\circ} 55^{\prime}-47^{\circ} 58^{\prime} \mathrm{W}\right)$, in the Federal District in Brazil. The average altitude is $1100 \mathrm{~m}$ and the climate is Aw type by Köppen classification.

The total tree flora $(\mathrm{dbh} \geq 10 \mathrm{~cm})$ consisted of 93 species, 81 genera and 44 families in 1985 (see Felfili 1993 and Felfili 1994). The sample size for the community (all species combined) and for the most abundant species in 1985 were: all species combined (with 1962 sampled individuals), Metrodorea pubescens (115), Amaioua guianensis (112), Guatteria sellowiana (103), Cheiloclinium cognatum (100), Licania apetala (100), Lamanonia tomentosa (94), Aspidosperma olivaceum (90), Protium brasiliense (85), Piptocarpha macropoda (83), Copaifera langsdorffii (74), Nectandra mollis (73), Tapirira guianensis (71), Cryptocarya aschersoniana (50), Maytenus alaternoides (49), Callisthene major (43), Emmotum nitens (36), Ouratea castaneaefolia (35), Cupania vernalis (34).

A total of 151 permanent plots, arranged in a systematic design in the area (Felfili 1993), was monitored every three years from 1985 to 1991 . The diameter and height distributions of the individuals and each species were analysed over this sixyear period. The analyses included all trees with dbh from $10 \mathrm{~cm}$ measured in 151 permanent plots of $10 \times 20 \mathrm{~m}$. The total sampled area was 3.02 ha. The height distribution for these trees and for all individuals from $5 \mathrm{~m}$ tall was also analysed. The $5 \mathrm{~m}$ height limit was chosen because it was the smaller size found for arboreal individuals from $10 \mathrm{~cm}$ dbh in this forest.

Individuals of the arboreal species under $10 \mathrm{~cm}$ dbh were sampled in subplots of different sizes. The subplots were placed within each $10 \times 20 \mathrm{~m}$ plot. Each subplot was placed on the left side at the beginning of the main plot. Thus, the $2 \times 2 \mathrm{~m}$ plot was within the $5 \times 5 \mathrm{~m}$ plot. This plot was within the $10 \times 10 \mathrm{~m}$ plot and this was within the $10 \times 20 \mathrm{~m}$ plot (see sampling design in Felfili 1993, 1995). They were sampled in subplots because the density of small individuals is much higher than the larger ones in the forests. Therefore, to reach a similar sampling intensity they should be sampled in different plot sizes. Some of these individuals reached more than $5 \mathrm{~m}$ and were subsequently included in the analyses of the height distribution. The relative density per ha per size class was used for the analyses.

The interval between diameter and height class (IC) of all individuals and all species combined was calculated according to Spiegel's (1976) formulae. This formulae calculate the ideal interval for distributing the data based in the amplitude and number of sampled individuals.

A semi-logarithmic regression was fitted to the diameter distribution to detect if it was balanced. The regression curve is expected to be linear in natural undisturbed forests (Meyer et al. 1961). A forest is balanced if the number of trees decreases geometrically with increasing size class. In a balanced forest recruitment is compensated by mortality so, the decreasing rate between the diameter classes should be constant. This type of distribution is known as Poisson distribution, reversed-J or typical. The differences between the slopes of the regression were also calculated. A small difference suggests little change over time (Freese 1962).

The differences between the diameter distributions for the three periods (1985-1988, 1985-1991, 1988-1991) were tested by a Kolmogorov-Smirnov two-sample test (Siegel \& Castellan Junior 1988).

During the field work the sociological position of each tree was recorded according to CENARGEM/EMBRAPA guidelines for in situ Genetic Reserves (Silva et al. 1987). Considering the diameter and height distributions in this forest, the sociological classifications made during the field work, and observations from other gallery forests in the same region, the species were grouped a posteriori into: emergents, upper and middle storey and lower-storey, as follow:

a) Emergents - big size trees, emerging from the upper storey, whose crows receive light from all directions; the largest trees reach between $60 \mathrm{~cm}$ and $100 \mathrm{~cm}$ diameter and more than $20 \mathrm{~m}$ height; E1: more than $30 \%$ of the total population were emergent trees; E2: more than $10 \%$ of the total population were emergent trees but the majority were dominant.

b) Upper and middle storey - the largest trees were smaller than $60 \mathrm{~cm}$ diameter and taller than $15 \mathrm{~m}$; D: dominants - big trees, immediately bellow the emergents forming the upper storey, whose crowns receive full light on top and partial light at the sides; and, C: codominants - medium sized trees suffering competition from the dominants, whose crowns receive full or partial light on top and relatively little at the sides.

c) Lower storey: the largest trees in this group are smaller than $30 \mathrm{~cm}$ diameter and $15 \mathrm{~m}$ height; L1: more than $15 \mathrm{~cm}$ diameter and $10 \mathrm{~m}$ height; L2: under $15 \mathrm{~cm}$ diameter and $10 \mathrm{~m}$ height.

Based on light requirements of natural regeneration (individuals under $10 \mathrm{~cm}$ dbh, see Felfili 1993, Felfili, 1997), some inferences were made on their light requirements:

a) Shade tolerants - regenerate and establish under closed canopy. b) Pioneers - the first colonizers in naturally disturbed areas such as gaps, edges with campo limpo or streambanks.

c) Non-pioneers light demanding - regenerate under a large variety of conditions but predominate and become established mostly in open canopy areas.

The bole (stem from ground level to the main ramifications forming the crown) shapes were also classified according to Silva et al. (1987). The relative and absolute numbers of trees per species and per bole type were calculated and analysed and the species were classified a posteriori in two broad categories: a) Straight, those with $50 \%$ or more individuals with boles 1 or 2 ; b) Tortuous, those with $50 \%$ or more individuals with boles 3 or 4 . 
The diameter and height distributions of the species were analysed to group those species with a similar structure. Only species with a minimum of 30 individuals sampled in 1985 occasion were considered.

\section{Results}

The community structure - The diameter distribution of all trees and species combined (from $10 \mathrm{~cm}$ diameter) showed a reversed-J shape, (figure 1). A linear regression of the logarithm of number of trees (Y) against the centre of each diameter classes (D) was well adjusted with high values of $r^{2}$. The equations where:

$$
\begin{aligned}
& Y(1985)=6.47-0.086 \ln (D), r^{2}=0.99 \\
& Y(1988)=6.48-0.0861 n(D), r^{2}=0.98 \\
& Y(1991)=6.40-0.084 \ln (D), r^{2}=0.95
\end{aligned}
$$

The greatest difference between the slopes of the equations occurred between 1991 and 1985, when they differed by approximately 0.08 (1.2\%).

Figure 1 shows the relative number of individuals by diameter classes. Approximately $95 \%$ of the individuals occurred up to $45 \mathrm{~cm}$. Figure 2 shows the relative number of species by diameter class. Some species occurred in several classes while others were restricted to fewer classes depending on their maximum diameter.

The height distribution of trees from $10 \mathrm{~cm}$ dbh was a bell-shaped curve with most individuals between $6 \mathrm{~m}$ and $18 \mathrm{~m}$ high, (figure 3 ). The distribution of all heights from $5 \mathrm{~m}$, also including natural

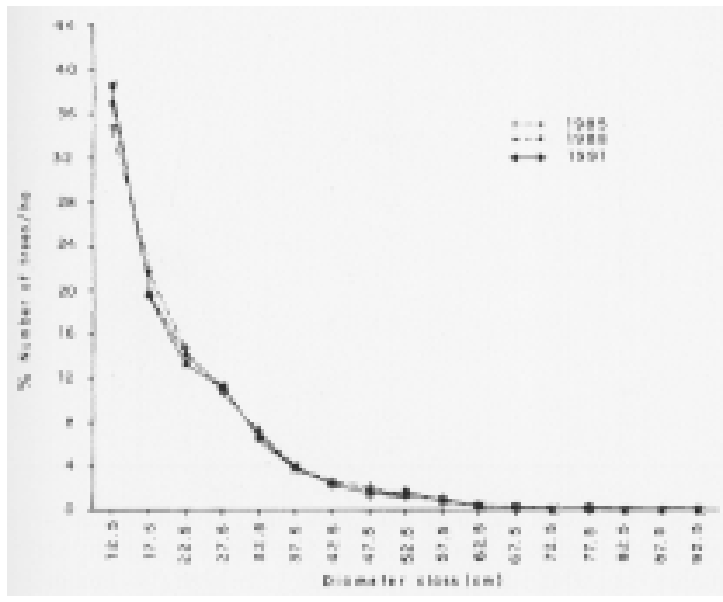

Figure 1. Diameter distribuition for all species combined in Gama gallery forest, Federal District, Brazil. Kolmogorov-Smirnov mnD $(85-88)=16,(88-91)=(85-91)=32 ; \operatorname{Tab}_{(0.10, \mathrm{~m}=\mathrm{n}=16)}=112 \mathrm{n}$.s. regeneration, showed a higher concentration of individuals in the smaller classes.

The vertical stratification (table 1) suggested the existence of a canopy layer approximately $20 \mathrm{~m}$ tall. Some emergent species reached between 20 and $30 \mathrm{~m}$. Straight boles predominated in the forest with $60 \%$ of the species having more than $50 \%$ of their boles straight (categories 1 and 2).

About $34 \%$ of the total number of trees reached the upper storey as dominant or emergents (table 1). Most of the emergent trees belonged to the species Aspidosperma olivaceum (Apocynaceae), Callisthene major, Qualea multiflora and $Q$.

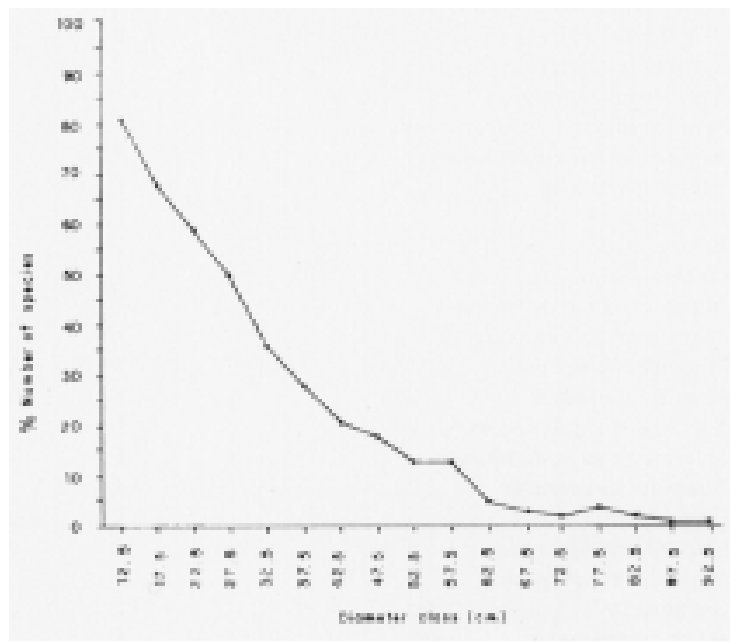

Figure 2. Distribution of species by maximum diameter class in Gama gallery forest, Federal District, Brazil.

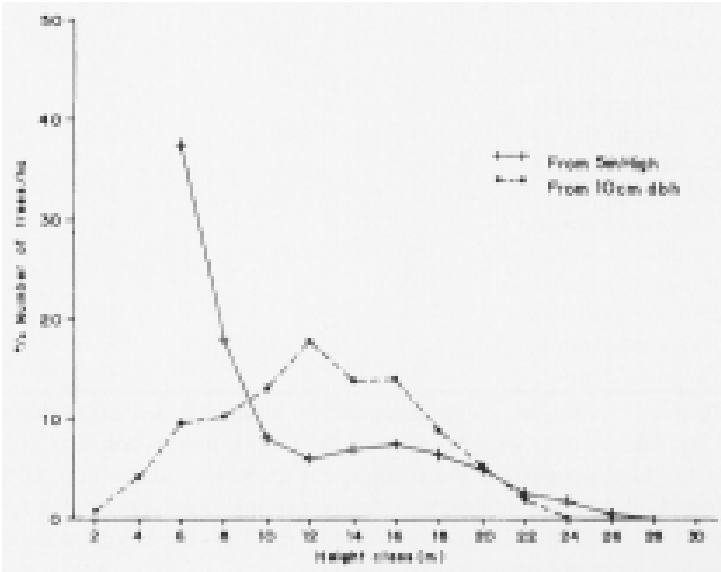

Figure 3. Height distribution in Gama gallery forest, Federal District, Brazil. 
Table 1. Bole classification, vertical stratification of the species, indications of light requirements and abundance of the tree species in the Gama gallery forest in Fazenda Água Limpa, Federal District, Brazil.

\begin{tabular}{|c|c|c|c|c|}
\hline Species & Boles $^{\mathrm{a}}$ & Stratification $^{\mathrm{b}}$ & Light $^{\mathrm{c}}$ & Abundance $^{\mathrm{d}}$ \\
\hline Aspidosperma olivaceum & 1 & E1 & LD & A \\
\hline Cobralea canjerana & 1 & E2 & LD & I \\
\hline Callisthene major & 1 & E1 & LD & A \\
\hline Copaifera langsdorffii & 1 & E1 & LD & A \\
\hline Cryptocarya aschersoniana & 1 & E2 & $\mathrm{ST}$ & A \\
\hline Lamanonia tomentosa & 2 & E1 & LD & A \\
\hline Nectandra mollis & 1 & E2 & ST & A \\
\hline Qualea multiflora & 1 & E1 & LD & I \\
\hline Tapirira guianensis & 1 & E2 & ST & A \\
\hline Terminalia brasiliensis & 1 & E1 & LD & $\mathrm{I}$ \\
\hline Terminalia argentea & 2 & E1 & LD & $\mathrm{I}$ \\
\hline Emmotum nitens & 1 & $\mathrm{D}$ & LD & A \\
\hline Licania apetala & 1 & $\mathrm{D}$ & ST & A \\
\hline Metrodorea pubescens & 1 & $\mathrm{D}$ & ST & A \\
\hline Piptocarpha macropoda & 1 & $\mathrm{D}$ & $\mathrm{P}$ & A \\
\hline Protium brasiliense & 1 & $\mathrm{D}$ & ST & A \\
\hline Apuleia leiocarpa & 1 & $\mathrm{D}$ & LD & I \\
\hline Alchornea iricurana & 1 & $\mathrm{D}$ & LD & $\mathrm{I}$ \\
\hline Aspidosperma cilyndrocarpon & 1 & $\mathrm{D}$ & LD & $\mathrm{I}$ \\
\hline Aspidosperma subincanum & 1 & $\mathrm{D}$ & LD & $\mathrm{I}$ \\
\hline Aspidosperma $\mathrm{sp}$ & 1 & $\mathrm{D}$ & LD & I \\
\hline Inga alba & 1 & $\mathrm{D}$ & $\mathrm{P}$ & $\mathrm{I}$ \\
\hline Persea fusca & 1 & $\mathrm{D}$ & $\mathrm{ST}$ & I \\
\hline Ormosia stipularis & 1 & $\mathrm{D}$ & LD & $\mathrm{I}$ \\
\hline Machaerium acutifolium & 1 & $\mathrm{D}$ & LD & $\mathrm{I}$ \\
\hline Maprounea guianensis & 1 & $\mathrm{D}$ & LD & $\mathrm{I}$ \\
\hline Micropholis venulosa & 3 & $\mathrm{D}$ & ST & $\mathrm{I}$ \\
\hline Myrsine coriacea & 1 & $\mathrm{D}$ & LD & $\mathrm{I}$ \\
\hline Saccoglottis guianensis & 1 & $\mathrm{D}$ & $\mathrm{ST}$ & I \\
\hline Sclerolobium paniculatum & 1 & $\mathrm{D}$ & $\mathrm{P}$ & I \\
\hline Amaioua guianensis & 3 & $\mathrm{C}$ & ST & A \\
\hline Cupania vernalis & 2 & $\mathrm{C}$ & ST & A \\
\hline Guatteria sellowiana & 1 & $\mathrm{C}$ & ST & A \\
\hline Matayba guianensis & 1 & $\mathrm{C}$ & ST & A \\
\hline Guapira sp. & 1 & $\mathrm{C}$ & ST & I \\
\hline Ixora warmingii & 3 & $\mathrm{C}$ & ST & I \\
\hline Ouratea castaneaefolia & 1 & $\mathrm{C}$ & LD & $\mathrm{I}$ \\
\hline Roupala montana & 2 & $\mathrm{C}$ & LD & $\mathrm{I}$ \\
\hline Salacia elliptica & 2 & $\mathrm{C}$ & ST & I \\
\hline Virola sebifera & 1 & $\mathrm{C}$ & ST & $\mathrm{I}$ \\
\hline Cheiloclinium cognatum & 2 & $\mathrm{~L} 1$ & $\mathrm{ST}$ & A \\
\hline Maytenus alaternoides & 2 & L1 & ST & A \\
\hline Alibertia macrophylla & 3 & L1 & ST & $\mathrm{I}$ \\
\hline Andira paniculata & 2 & L1 & ST & $\mathrm{I}$ \\
\hline Dalbergia sp. & 2 & L2 & ST & I \\
\hline Diospyros hispida & 2 & L1 & $\mathrm{ST}$ & $\mathrm{I}$ \\
\hline Miconia sp. & 2 & L2 & ST & $\mathrm{I}$ \\
\hline Jacaranda caroba & 1 & L1 & $\mathrm{P}$ & $\mathrm{I}$ \\
\hline Pouteria ramiflora & 2 & L1 & $\mathrm{ST}$ & I \\
\hline Rapanea guianensis & 1 & L2 & ST & $\mathrm{I}$ \\
\hline Rheedia brasiliense & 1 & L2 & ST & $\mathrm{I}$ \\
\hline Rubiaceae Indet. & 1 & L2 & ST & $\mathrm{I}$ \\
\hline Talauma ovata & 1 & L2 & ST & I \\
\hline
\end{tabular}

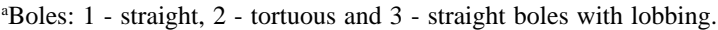

${ }^{\mathrm{b} S t r a t i f i c a t i o n: ~ e m e r g e n t ~ s p e c i e s ~-~ t h e ~ l a r g e s t ~ t r e e s ~ r e a c h ~ b e t w e e m ~} 60 \mathrm{~cm}$ to $100 \mathrm{~cm}$ dbh and more than $20 \mathrm{~m}$ high (E1 - more than $30 \%$ of the total population were emergent trees; E2 - more than $10 \%$ of the total population were emergent trees but the marjority were dominants); upper and middle storey species - the largest trees were smaller than $60 \mathrm{~cm}$ dbh and higher than $15 \mathrm{~m}$ high (D - dominant and C - codominant); lower storey species ( $\mathrm{L} 1$ - the largest trees are more than $15 \mathrm{~cm}$ diameter and $10 \mathrm{~m}$ high; L2 - the largest trees are under $15 \mathrm{~cm}$ diameter and $10 \mathrm{~m}$ high). 'Light: LD - non pioneer light demanding; ST - shade tolerant; P - pioneer.

${ }^{\mathrm{d}}$ Abundance: A - abundant species, with more tham ten trees/ha (number of sampled trees $\mathrm{n}$ ranged from 30 to 94); I - species occuring at intermediate density (n ranged from 10 to 29). 
dichotona (Vochysiaceae), Copaifera langsdorffii (Leguminosae), Lamanonia tomentosa (Cunoniaceae), Terminalia argentea e T. brasiliensis ( Combretaceae), Cryptocarya aschersoniana and Nectandra mollis (Lauraceae) and Tapirira guianensis (Anacardiaceae) also had some emergent trees but most of them were dominant.

Most of the individuals of Cheiloclinium cognatum and Salacia elliptica (Hippocrateaceae), Maytenus alaternoides (Celastraceae), Styrax guianensis (Styracaceae), Rapanea guianensis (Myrsinaceae), some species of Myrtaceae, Rubiaceae, Melastomataceae and Vismia sp. (Guttiferae) were restricted to the lower storey.

A third of the 18 most abundant species studied here, showed a decreasing distribution. Nevertheless, only two, Calisthene major and Lamanonia tomentosa had an accentuated shortage of individuals in the smaller classes (see the curves for all species in Felfili 1993). Most species showed intermediate patterns.

Diameter distribution of the species - The maximum diameter reached by the lower storey species such as Cheiloclinium cognatum, was between $25-30 \mathrm{~cm}$, (figure 4). The more abundant species in the group had reversed-J distributions.

Middle storey species, such as Amaioua guianensis, reached between $35 \mathrm{~cm}$ and $40 \mathrm{~cm}$ diameter (figure 5). Their distributions followed the

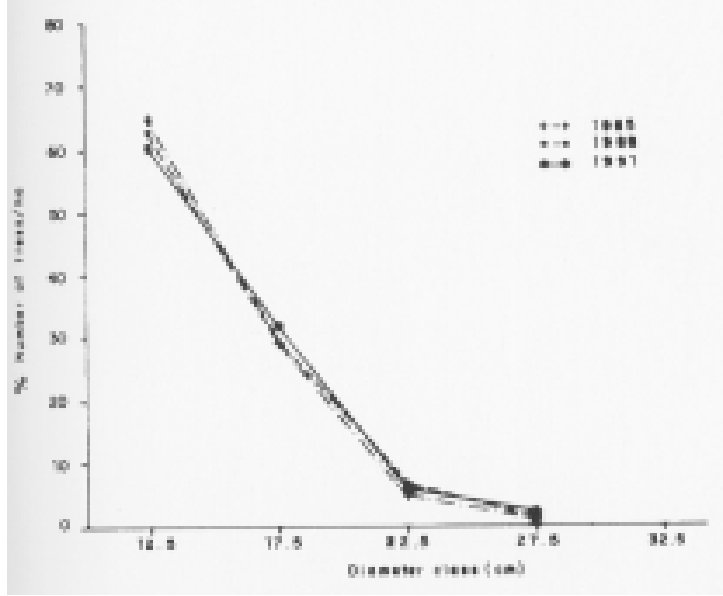

Figura 4. Diameter distribution of Cheiloclinium cognatum in Gama gallery forest, Federal District, Brazil. Kolmogorov-Smirnov mnD

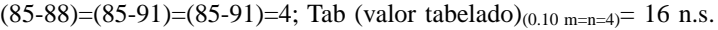
(não significativo). same pattern as the previous group. The diameter limits were similar for the upper storey species Piptocarpha macropoda, but the distribution was less regular, (figure 6).

Some upper storey species, such as Metrodorea pubescens, reached between $40 \mathrm{~cm}$ and $45 \mathrm{~cm}$. The distribution showed either a small concentration or shortage of the individuals in some intermediate classes (figure 7).

The tallest emergent species such us Lamanonia tomentosa (figure 8) reached between $60 \mathrm{~cm}$ to

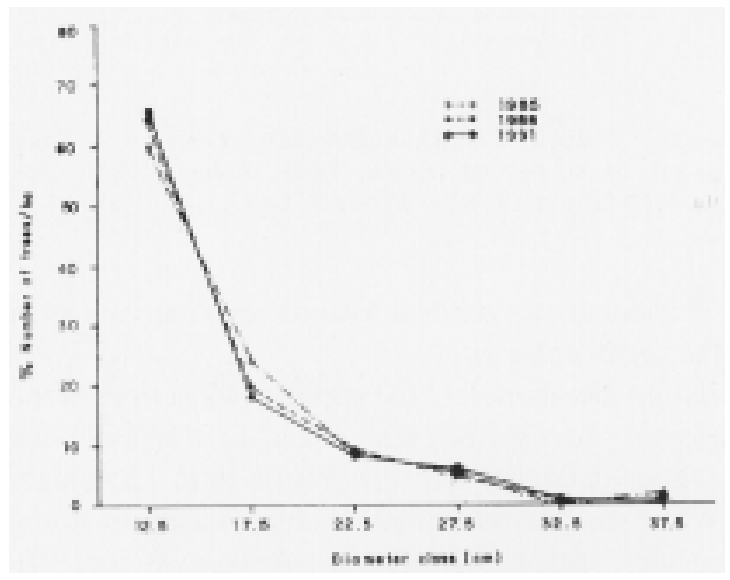

Figura 5. Diameter distribution of Amaioua guianensis in Gama gallery forest, Federal District, Brazil. Kolmogorov-Smirnov mnD $\left.(85-88)=(88-91)=(85-91)=5 ; T^{2} b_{(0.10} \mathrm{m}=\mathrm{n}=5\right)=24 \mathrm{n} . \mathrm{s}$.

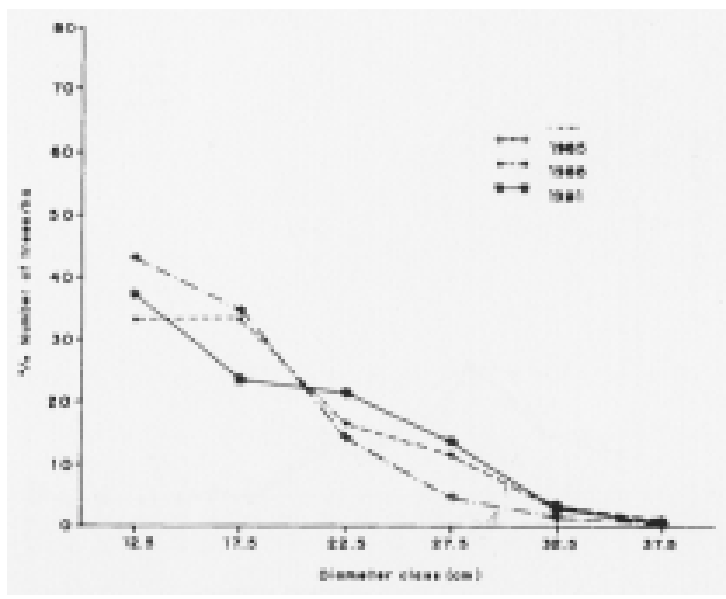

Figura 6. Diameter distribution of Piptocarpha macropoda in Gama gallery forest, Federal District, Brazil. Kolmogorov-Smirnov mnD $(85-88)=10,(88-91)=(85-91)=5$; $\operatorname{Tab}_{(0.10 \mathrm{~m}=\mathrm{n}=5)}=20 \mathrm{n} . \mathrm{s}$. 


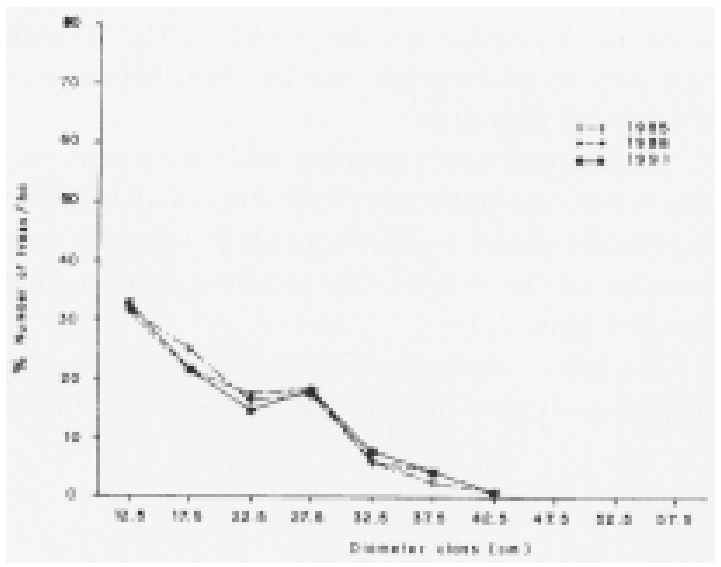

Figura 7. Diameter distribution of Metrodorea pubescens in Gama gallery forest, Federal District, Brazil. Kolmogorov-Smirnov mnD $(85-88)=14,(88-91)=(85-91)=7 ; \operatorname{Tab}_{(0.10 \mathrm{~m}=\mathrm{n}=7)}=35$ n.s.

$95 \mathrm{~cm}$ diameter and had a shortage of individuals in the smaller classes.

Height distribution of the species - Most trees of the lower storey species, such as Cheiloclinium cognatum (figure 9), were from $8 \mathrm{~m}$ to $12 \mathrm{~m}$ high. While most trees from $10 \mathrm{~cm}$ dbh of the upper storey species, such as Metrodorea pubescens (figure 10), were from $14 \mathrm{~m}$ to $20 \mathrm{~m}$.

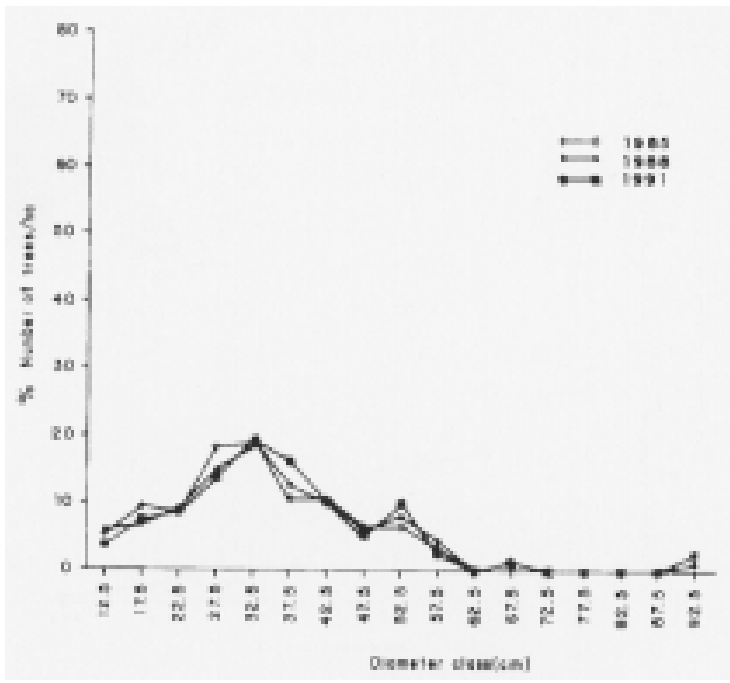

Figura 8. Diameter distribution of Lamanonia tomentosa in Gama gallery forest, Federal District, Brazil. Kolmogorov-Smirnov mnD $(85-88)=12,(88-91)=(85-91)=24 ; T^{2} b_{0.10} m=n=12=72$ n.s..

\section{Discussion}

The community structure - The shape of the diameter distribution (figure 1) was typical of self-regenerating communities. Small trees represented most of the population (Meyer et al. 1961, Harper 1977). A semilogarithmitic regression well adjusted to the data suggested the balance between mortality and recruitment (Meyer et al. 1961). This relationship was similar over the six years with little difference between the slopes of the regressions (Freese 1962).

The forest was composed mainly of species with small individuals, under $45 \mathrm{~cm}$ dbh (figure 1 and 2). Ramos (1989) also found a similar diameter structure for a dry mesophytic forest that occurs in the same region but on mesotrophic soils on limestone outcrops. In both forests, the largest trees reached around $100 \mathrm{~cm}$ diameter and occurred at low densities. On the other hand, in cerrado sensu stricto (the predominant woody vegetation that surrounds the gallery forests), the size range is much smaller. Most of the species and individuals are under $10 \mathrm{~cm}$ diameter (Felfili \& Silva Junior 1988, Silva Junior \& Silva 1988, Nascimento \& Saddi 1992). Gallery forests grow in the same acidic, aluminium rich and nutrient poor soils as the surrounding cerrado sensu stricto (Felfili 1993, 1994). However, they reach similar dimensions to the mesophytic forest. The soil humidity and the organic matter layer produced and

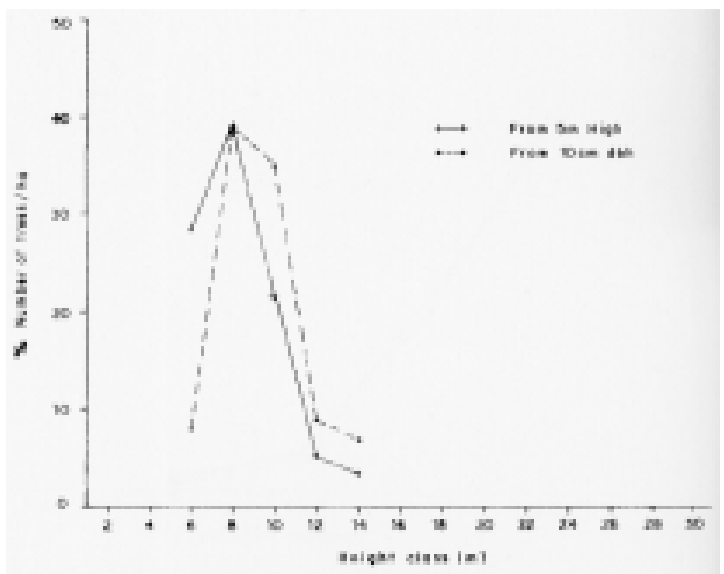

Figura 9. Height distribution of a lower storey species Cheiloclinium cognatum, in Gama gallery forest, Federal District, Brazil. 


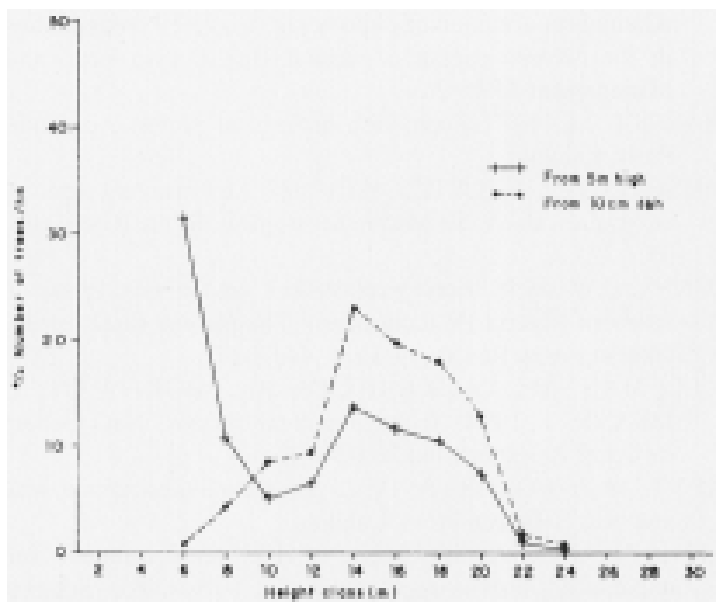

Figura 10. Height distribution of an upper storey shade-tolerant species, Metrodorea pubescens, in Gama gallery forest, Federal District, Brazil.

maintained by the forest supply the conditions for their existence.

Only a few individuals $(1.01 \%$ of the total, see figure 1) of eleven species and seven families (see Felfili 1993) reached more than $60 \mathrm{~cm}$ : Cryptocarya aschersoniana and Nectandra mollis (Lauraceae), Copaifera langsdorffii (Leguminosae Caesalpinoideae), Callisthene major, Qualea dichotoma and Q. Multiflora (Vochysiaceae), Cabralea canjerana (Meliaceae), Lamanonia tomentosa (Cunoniaceae) Tapirira guianensis (Anacardiaceae), Terminalia argentea and T. brasiliensis (Combretaceae). Large emergent trees of the families Leguminosae, Lauraceae and Vochysiaceae are common in the neotropics. Their ability to fix nitrogen, as shown by the Leguminosae and that of the accumulating aluminium by the Vochysiaceae (Haridasan \& Araujo 1988) probably is a competitive advantage in this environment.

The height distribution (figure 3 ) also suggested that this is a self-regenerating community. The gallery forests trees seem to reach intermediate size when compared to rainforest formations. Therefore, the tallest trees in this gallery forest are Mesophanerophytes according to Raunkaier's life form classification (Kent \& Coker 1992). Kellman et al. (1994) studying gallery forests in Belize and Venezuela also found most trees under $20 \mathrm{~m}$ high and $50 \mathrm{~cm}$ diameter.
Cariniana estrellensis (Lecythidaceae) was found only in the understorey (table 1) and at very low density. However, large trees of this species occur in similar forests in the region. Either there is a limiting factor for its growth, or it has only started to colonize this forest. This tendency was also noticed for other species, such as Luehea paniculata (Tiliaceae), which also reach larger dimensions in neighbouring gallery forests.

This forest is characterized by most species occurring at low densities. Eighteen species, representing less than $20 \%$ of all tree species, made up more than $50 \%$ of the total individuals. Their densities ranged from approximately 10 trees/ha for the least to 31 trees/ha for lhe most numerous (see Felfili 1993, 1994). Six of these species were in the middle and lower stories, five were dominants and seven were emergents. Therefore, the dominant species occupied different positions in the canopy and seem to have distinct light requirements (table 2 ). This may be one of the factors that allow them to coexist in abundance.

Diameter and height distribution of the species The most abundant middle and lower storey species showed a reversed-J pattern for their diameter distribution. The curves were smoother for the upper storey species. Their trees were less concentrated in the smaller classes than those in the previous group. The rates of decrease between successive classes were also smaller than those found for the lower storey. Most of the tallest emergent species had a shortage of individuals in the smaller classes. Mortality has not been compensated by recruitment over a relatively long period if the diameter distribution did not follow the reversed$\mathrm{J}$ pattern in the studied site. An indication of this is that the density of Lamanonia tomentosa has been decreasing in the study-area. Some other emergent species also follow this pattern (see Felfili 1993, 1995).

The species with relatively few individuals in the smaller classes and a higher concentration in the intermediate or larger classes probably had more small individuals in the past. This pattern of diameter distribution was also described by Jones (1956) for some emergent species in Nigeria. It seems that the large emergent trees are light demanding. Possibly, the current adult trees established themselves in the forest in a past period when large gaps were more 
frequent. The shortage of juveniles may be due to insufficient light supply to allow the same rate of establishment. These species may need a larger spatial or temporal scale to regenerate. That could be assessed by a longer term monitoring of these permanent plots and by surveying more sites in the hydrographycal basin.

The most abundant species occupied different positions in the canopy and have different size structures. These may be among the causes of their dominance in the site.

There was little change in number and distribution either of lhe community or of the individual species over the six years studied suggesting that this community tend to be in equilibrium.

Acknowledgements - I thank Mr. Howard Wright, Dr. Timmothy Synnot, Dr. Quentin Cronk and Mr. Christopher Fagg from the Oxford Forestry Institute for the comments on the manuscript; Mr. Newton Rodrigues from the University of Brasília for field assistance; Brazilian Research Council $(\mathrm{CNPq})$, for Financial support.

\section{References}

CAMPBELL, D.G., STONE, J.L. \& ROSAS JUNIOR, A. 1992. A comparison of the phytosociology and dynamics of three foodplain (Várzea) forests of known ages, Rio Juruá, western Brazilian Amazon. Bot. J. Linn. Soc. London 108:213-237.

CLARK, D.A. \& CLARK, D.B. 1987. Análisis de la regeneración de árboles del dosel en bosque muy húmedo tropical: aspectos teóricos y practicos. Revta Biol. Tropical 35:41-54 (suppl.).

CLARK, D.A \& CLARK, D.B. 1992. Life history diversity of canopy and emergent trees in a neotropical rain forest. Ecol. Monogr. 62:315-344.

FELFILI, J.M. 1983. Avaliação do potencial florestal e dos resíduos de exploração das florestas do norte de Mato Grosso. Tese de mestrado. Universidade Federal de Viçosa, Viçosa.

FELFILI, J.M. 1993. Structure and dynamics of a gallery forest in central Brazil. PhD Thesis. University of Oxford, Oxford.

FELFILI, J.M. 1994. Floristic composition and phytosociology of the gallery forest alongside the Gama stream in BrasíliaDF in Brazil. Revta brasil. Bot. 17:1-11.

FELFILI, J.M. 1997. Dynamics of the natural regeneration in the Gama gallery forest in central Brazil. For. Ecol. and Management (no prelo).

FELFILI, J.M. 1995. Growth, recruitment and mortality in the Gama gallery forest in central Brazil over a six-year period (1985-1991). J. Trop. Ecol. 11:67-83.

FELFILI, J.M. \& SILVA JUNIOR, M.C. 1988. Distribuição dos diâmetros numa faixa de Cerrado na Fazenda Água Limpa (FAL) em Brasília-DF. Acta Bot. Bras. 2:85-104.

FREESE, F. 1962. Statistics for land managers. Paeone Press, Jedburgh.
HARIDASAN, M. \& ARAUJO, G.M.1988. Aluminiumaccumulating species in two forest communities in the cerrado region of central Brazil. For. Ecol. and Management 24:15-26.

HARPER, J.L. 1977. Population biology of plants. Academic Press, London.

HUBBELL, S.P. \& FOSTER, R.B. 1987. La estructura espacial en gran escala de un bosque neotropical. Revta Biol. Trop. 35:7-22.

JONES, E.W. 1956. Ecological studies on the rain forest of southern Nigeria IV (continued). The plateau forest of the Okumu Forest Reserve. J. Ecol. 44:83-117.

KELLMAN, M., TACKABERRY, R., BROKAW, N. \& MEAVE, J. 1994. Tropical gallery forests. Nat. Geogr. Research \& Exploration 10:92-103.

KENT, M \& COKER, P. 1992. Vegetation description and analysis. Belhaven Press, London.

LEAK, W. 1964. An expression of diameter distribution for unbalanced, uneven-aged stands and forests. For. Science 10:39-50.

MacDOUGALL, A. \& KELLMAN, M. 1992. The understorey light regime and patterns of tree seedlings in tropical riparian forest patches. J. Biogeogr. 19:667-675.

MEYER, H.A., RECKNAGEL, A.B., STEVENSON, D.D. \& BARTOO, R.A. 1961. For. management. Ronald Press, New York.

MOREIRA, A.G. 1987. Aspectos demográficos de Emmotum nitens (Benth.) Miers (Icacinaceae) em um cerradão distrófico no Distrito Federal. Tese de mestrado, Universidade Estadual de Campinas, Campinas.

NASCIMENTO, M.T. \& SADDI, N. 1992. Structure and floristic composition in an area of cerrado in CuiabáMT. Revta brasil. Bot. 15:47-55.

OLIVEIRA, P.E.A.M., RIBEIRO, J.F. \& GONZALES, M.I. 1989. Estrutura e distribuição espacial de uma população Kielmeyera coriacea Mart. de cerrados de Brasília. Revta brasil. Bot. 12:39-48.

OLIVEIRA-FILHO, A.T., SCOLFORO, J.R.S. \& MELO, J.M. 1994. Composição florística e estrutura comunitária de um remanescente de floresta semidecídua montana em Lavras, MG. Revta brasil. Bot. 17:167-182.

RAMOS, P.C.M. 1989. Estudos fitossociológicos em uma floresta mesofitica semidecídua na Fercal, Brasília - DF. Tese de mestrado, Universidade de Brasília, Brasília.

RICHARDS, P.W. 1952. The tropical rain forest. Cambridge University Press, Cambridge.

SIEGEL, S. \& CASTELAN JUNIOR, N.T. 1988. Nonparametric statistics for the behavioral sciences. MacGraw-Hill, New York.

SILVA JUNIOR, M.C. \& SILVA, A.F. 1988. Distribuição dos diâmetros dos troncos das espécies mais importantes do Cerrado na Estação Florestal de Experimentação de Paraopeba (EFLEX)-MG. Acta Bot. Bras. 2:107-126.

SILVA, J.A., LEITE, E.J. \& GRIPP, A. 1987. Procedimento para cadastramento e mapeamento de matrizes em Reservas Geneticas Florestais in situ. EMBRAPA/CENARGEN, Brasília.

SPIEGEL, M.P. 1976. Estatística. Mc.Graw-Hill, São Paulo. 